\title{
Radioactivity concentrations of uranium, thorium and potassium in the soil around Baiyan Obo, China
}

\author{
WANG NANPING*, ZENG WEIHUA,
}

\section{LIU HONGTAO}

${ }^{1}$ School of Geophysics and Information Technology, China University of Geosciences, Beijing, 100083, China

(*correspondence: npwang@cugb.edu.cn)

The mining and application of ores containing natural radioactive materials will lead to an increase of natural radioactive material content and the radiation dose in the local. The Baiyan Obo Iron Mine, located in the northern of China, is the world's largest open-pit mining mine with rare earth minerals. Fine monazite containing thorium-232 element is filled in the ore-bearing dolomite cracks [1]. So thorium-232 in tailings slag after iron ore dressing and smelting is high, and natural radionuclides from open-pit mining and tailings dams may be enriched in the soil [2].

A total of 87 soil samples were collected with a depth from 0 to $5 \mathrm{~cm}$ from the ground. Then the activity of uranium, radium, thorium and potassium in the samples was determined using an indoor high-purity germanium gammaray spectrometer. The average activity concentration of thorium-232 in the tailings slag is $1209.1 \pm 149.2 \mathrm{~Bq} / \mathrm{kg}$, while the activity concentrations of radium and potassium are very Low; the average activity concentration of thorium-232 observed in the surrounding soil was as high as $79.8 \pm 139.0$ $\mathrm{Bq} / \mathrm{kg}$, with a range of 17.0-816.9 Bq/ kg. We found that the thorium contents were high in the soil near the tailings dam and the mining site. Except for thorium-232 element, the contents of uranium, radium and potassium are similar to that of normal background area. The areas of local thorium-232 pollution are consistent with the zones delineated by the insitu gamma-ray spectrometer method [3].

The survey data show that the mining and development of the Baiyun Obo Iron Mine has led to an increase in the concentration of thorium-232 radionuclides in the soil near the mining site and the tailings dam.

This research was supported by the National Natural Science Foundation of China (No. 41674111).

[1] Yang K. et al. (2011). Ore Geol. Rev. 40, 122-131. [2] Wang X. et al. (2009). Radiat. Prot. 29, 270-274. [3] Li B. et al. (2016). J. Environ. Radioact. 151, 304-310. 